\title{
PERLUASAN KEWENANGAN BADAN PEMERIKSA KEUANGAN DALAM MENGAWASI KEUANGAN NEGARA DI LINGKUP PEMERINTAHAN DAERAH
}

\author{
Dani Habibi \\ Fakultas Hukum, Universitas Nahdlatul Ulama Surakarta \\ email: danihabibi45unusurakarta@gmail.com \\ Ian Aji Hermawan \\ Fakultas Hukum, Universitas Nahdlatul Ulama Surakarta \\ email: ianajiher2020unusurakarta@gmail.com
}

disampaikan 02/10/19 - di-review 07/06/2020 - diterima 03/12/2020

DOI: $10.25123 /$ vej.3512

\begin{abstract}
State budget management is tightly related to how the existing state law regulates fiscal relationship between the central government and the regional-local governments. The authority granted to regional-local government to manage their own budgeting more or less autonomously in practice results in mismanagement, misuse of available financial resources and even corruption. Unfettered and unchecked financial leakage at the regional government level may and have resulted in failure to realize and implement projects much needed by society. In light of this situation, a justified need arise for state intervention to monitor-control planning and realization of regional-local government budget. The author proposed the expansion of the Audit Board of the Republic Indonesia's authority. They should not passively wait for financial reports to be submitted but actively assist regional-local government in planning their own budget, monitor the spending and realization of it and lastly, provide assistance in drafting the final report.
\end{abstract}

Keywords:

State Finance, State financial loss, regional government, Regional-National Budget.

\begin{abstract}
Abstrak
Pengelolaan keuangan Negara sekaligus bersentuhan dengan pengaturan hubungan keuangan antara pemerintah pusat dan pemerintah deerah. Kewenangan yang diberikan pada pemerintah daerah untuk mengelola keuangannya, kurang lebih secara mandiri dalam kenyataan justru membuka peluang penyelewengan anggaran bahkan korupsi. Kebocoran keuangan daerah yang tidak terkendali itu pada akhirnya mengakibatnya banyak program kerja daerah tidak terwujud. Kenyataan ini sekaligus memunculkan kebutuhan akan adanya pengawasan-pengendalian penggunaan keuangan di daerah oleh pemerintah pusat. Berkenaan dengan itu, penelitian yang dilakukan perihal persoalan di atas memunculkan rekomendasi perlu perluasan kewenangan Badan Pemeriksa Keuangan (BPK) untuk tidak sekadar menunggu penyampaian laporan keuangan tiap satuan perangkat pemerintah, namun lebih dari itu turut mengawasi perancangan APBD sampai dengan realisasi dan pelaporannya.
\end{abstract}

Kata kunci: Keuangan Negara, Kerugian Negara, Pemerintahan Daerah, Anggaran Pendapatan dan Belanja Daerah (APBD) 


\section{Pendahuluan}

Badan Pemeriksa Keuangan (BPK) merupakan suatu lembaga yang hadir di dalam sistem ketatanegaraan Indonesia yang memiliki tujuan untuk melakukan pemeriksaan terhadap keuangan negara sebagaimana diamanatkan di dalam Pasal 23E ayat (1) Undang-Undang Dasar Negara Republik Indonesia Tahun 1945 (UUD NRI Tahun 1945) ${ }^{1}$. BPK sudah ada sejak awal kemerdekaan, kemudian telah disempurnakan perihal tugas dan wewenang yang telah dirumuskan di dalam UUD NRI Tahun 1945 dan Undang-Undang Nomor 15 Tahun 2006 tentang Badan Pemeriksa Keuangan (UU BPK). Pada era reformasi menjadi sebuah pembukaan awal masa pemusatan pemerintahan yang semula semua tertuju pada pemerintahan pusat sekarang berubah menjadi adanya pemisahan kekuasaan antara pemerintah pusat dengan pemerintah daerah sebagai salah satu pencapaian reformasi yang terjadi.

Permasalahan muncul pada era reformasi, yaitu adanya keinginan suatu daerah agar dapat mengurus kepentingan daerahnya sendiri dan juga memunculkan banyaknya permasalahan Korupsi, Kolusi, dan Nepotisme (KKN) yang malah makin menyebar pasca reformasi. ${ }^{2}$ Terbukti dari adanya pemeriksaan BPK terhadap Ikhtisar Hasil Pemeriksaan Semester (IHPS) baik periode I dan II dimulai tahun 2015 hingga 2018 menunjukkan masih dilakukannya pelanggaran tentang pengelolaan keuangan negara yang dilakukan oleh pemerintah daerah yang berkaitan dengan hal-hal yang sama pelanggaran yang dilakukan. Hal ini membuat adanya suatu kumulasi kerugian keuangan negara yang dilakukan oleh pemerintah daerah dikarenakan penggunaan anggaran yang tidak sesuai dengan peraturan perundang-undangan dan adanya penyusunan suatu anggaran yang tidak tepat sasaran. ${ }^{3}$

1 Muhammad Imron Rosyadi, Wewenang Badan Pemeriksa Keuangan dan Badan Pengawasan Keuangan dan Pembangunan dalam Menilai Kerugian Keuangan Negara, Mimbar Keadilan, Jurnal Ilmu Hukum Januari - Juni 2016, Surabaya, 2016, hlm., 28.

2 Bambang Waluyo, Optimalisasi Pembrantasan Korupsi Di Indonesia, Jurnal Yuridis Vol. 1 No. 2, Desember 2014, Jakarta, 2014, hlm., 176.

3 Ikhtisar Hasil Pemeriksaan Semester II Tahun 2018 oleh Badan Pemeriksa Keuangan 
Perlu dilakukan suatu rancangan konsep yang harus ada di dalam peraturan perundang-undangan bahwa UU BPK serta undang-undang lainnya yang berkaitan dengan kinerja BPK perlu dilakukan revisi untuk memperluas kewenangan BPK dalam memeriksa keuangan negara sesuai yang diamanatkan oleh UUD NRI Tahun 1945. ${ }^{4}$ Meskipun adanya peringatan akan adanya hukuman administrasi dan pidana bagi pejabat-pejabat daerah maupun kepala instansi yang berkaitan dengan pengelolaan keuangan negara, namun tidak membuat patuh untuk segera melaksanakan rekomendasi dari BPK dalam upaya untuk mengganti kerugian keuangan negara.

Penelitian ini menggunakan metode pendekatan normatif, yaitu pendekatan yang mengkaji peraturan perundang-undangan, guna mengetahui kelebihan dan kekurangan dari undang-undang tersebut, dalam hal ini yang kita kaji adalah UU BPK beserta dengan peraturan pendukungnya. Sebagai bentuk evaluasi bagi BPK sehingga memunculkan adanya suatu konsep terbaru perlu adanya perluasan kewenangan BPK dalam memeriksa keuangan negara guna meminimalisir dan bahkan mencegah terjadinya suatu kerugian keuangan negara.

\section{Pembahasan}

\section{Politik Hukum BPK serta Permasalahannya}

BPK adalah suatu lembaga negara yang keberadaanya dilindungi oleh undang-undang sehingga dalam menjalankan kewajiban dan kewenangannya pun harus sesuai dengan undang-undang dengan kata lain harus bersifat independen meskipun para komisionernya dilantik oleh Presiden.

Apapun yang di jalankan maupun kebijakan yang dibuat oleh BPK harus sesuai dengan undang-undang yang telah ditetapkan baik UUD NRI 1945 maupun undang-undang BPK. Meskipun tidak dapat dipungkiri dalam pembentukan undang-undang BPK sarat kepentingan politik selain kepentingan hukum itu

4 Andini Rahmayanti Pontoh, Tugas dan Wewenang BPK dalam Pengawasan Pengelolaan Keuangan BUMN/D, Lex Administratum, Vol.I/No.1/Jan-Mrt/2013, Sulawesi Utara, 2013, hlm., 133-134. 
sendiri. Hal itu wajar karena DPR selain lembaga legislatif juga sebagai lembaga politik.

Laica Marzuki dalam bukunya yang berjudul Berjalan-jalan di Ranah Hukum, menyampaikan pendapat bahwa, "undang-undang adalah produk politik niscaya setiap undang-undang memuat pesan-pesan politik berpaut dengan kepentingan politik". ${ }^{5}$ Sedangkan menurut Jimly Asshiddiqie, proses pembuatan hukum itu melalui serangkaian perdebatan parlemen yang berasal dari berbagai latar belakang partai politik berbeda, sehingga fungsi dan peran hukum sangat dipengaruhi dan bahkan seringkali diintervensi oleh kekuatan pola seperti kepresidenanatik yang ada di parlemen. ${ }^{6}$

Perubahan undang-undang BPK terutama terkait kewenangannya dalam memeriksa keuangan pemerintah daerah dimaksudkan agar sistem pengelolaan keuangan negara menjadi lebih baik dari masa sebelumnya yang dianggap mempunyai banyak kelemahan serta sarat dengan tindakan KKN.

Tujuan dari reformasi salah satunya adalah supremasi hukum dan penegakkan hukum yang selama masa orde baru tidak dapat terealisasi dengan nyata dengan kata lain penuh dengan rekayasa. Termasuk keberadaan BPK tidak dapat maksimal dalam melakukakan pengawasan pengelolaan keuangan lembaga negara seperti lembaga kepresidenan, DPR, MPR dan DPR serta lembaga negara lainnya.

Albert Hasibuan mengemukakan perlunya evaluasi hukum berdasarkan pembaruan hukum untuk yang lebih baik, tujuannya agar hukum itu menjadi efektif.7 Seperti diketahui, efektivitas hukum, berkaitan dengan peranan hukum sebagai alat atau instrumen untuk tujuan politik reformasi yang demokratis

5 M. Laica Marzuki, Berjalan-jalan di Ranah Hukum: Pikiran-Pikiran Lepas Prof. Dr. H. M. Laica Marzuki, S.H., Konstitusi Press, Jakarta, 2005, hlm., 70.

6 Jimly Asshiddiqie, Hukum Tata Negara dan Pilar-Pilar Demokrasi, Serpihan Pemikiran Hukum, Media dan HAM, Konstitusi Press, Jakarta, 2005, hlm., 7.

7 Romli Atmasasmita, Pengantar Hukum Kejahatan Bisnis, Kencana, Jakarta, 2003, hlm., 49. 
berdasarkan UUD NRI Tahun 1945 dengan melaksanakan nilai-nilai dari prinsip negara hukum. ${ }^{8}$

UU BPK dibentuk pada tahun 2006 dengan tujuan baik Pemerintah Pusat, Pemerintah Daerah, Badan Usaha Milik Negara (BUMN), maupun Badan Usaha Milik Daerah (BUMD) dapat mengelola keuangan negara dengan sebaik-baiknya dan mengindari adanya suatu kerugian negara. Karenanya BPK melakukan suatu pemeriksaan laporan keuangan terhadap satuan pemerintahan maupun badan usaha yang dirumuskan di dalam Ikhtisar Hasil Pemeriksaan Semester (IHPS) selama 2 (dua) kali pemeriksaan dalam setahun. Berdasar hal tersebut menunjukkan terjadi ketimpangan dalam penyelesaian rekomendasi yang diberikan dari BPK kepada satuan pemerintahan ataupun badan usaha. Mengacu tabel di bawah ini berkaitan dengan pemeriksaan pada satuan pemerintahan daerah memperlihatkan masih banyaknya rekomendasi yang tidak dilaksanakan yang berimplikasi pada kerugian negara yang tidak bisa dipertanggungjawabkan. Berikut tabel data realisasi pelaksanaan Tindak Lanjut Rekomendasi Hasil Pemeriksaan (TLRHP) maupun penyelesaian ganti rugi yang dilakukan Pemerintah Daerah (BPK-IHPS Semester II 2018).

Tabel 1: Ikhtisal Hasil Pemeriksaan Semester II Bagian Pemerintah Daerah

\begin{tabular}{cccccc}
\hline $\begin{array}{c}\text { Pemerintah } \\
\text { Daerah } \\
\text { (Periode) }\end{array}$ & $\begin{array}{c}\text { Jumlah } \\
\text { Rekomendasi }\end{array}$ & Nilai & $\begin{array}{c}\text { Sesuai } \\
\text { Rekomendasi }\end{array}$ & Total Nilai & \% \\
\hline $2005-2009$ & 116.239 & 15.601 .788 .349 .549 & 99.341 & 8.465 .244 .979 .354 & $85,5 \%$ \\
\hline $2010-2014$ & 185.177 & 20.417 .555 .412 .317 & 144.806 & 10.113 .614 .665 .484 & $78,2 \%$ \\
\hline $2015-2018$ & 422.390 & 65.132 .603 .730 .122 & 320.290 & 26.105 .491 .894 .072 & $75,8 \%$ \\
\hline
\end{tabular}

Sumber: Ikhtisar Hasil Pemeriksaan Semester (IHPS) II. Jakarta: Badan Pemeriksa Keuangan, Jakarta, 2018, hlm., 590.

Data di atas dapat dicermati bahwa mulai tahun 2005-2009 menunjukkan pelaksanaan sesuai dengan rekomendasi sebesar 85,5\% dari 100\% terhadap rekomendasi yang harus dilaksanakan. Namun mulai tahun 2010-2014 mengalami penurunan kepatuhan untuk segera melakukan rekomendasi dari BPK. Hal itu

$8 \quad$ Erman Rajagukguk, et.al., Perubahan Hukum di Indonesia (1998-2004), Harapan 2005, Legal Development Facility - Fakultas Hukum Universitas Indonesia, Jakarta, 2004, hlm., 12. 
dapat terlihat di tabel tahun 2010-2014 menunjukkan pelaksanaan sesuai dengan rekomendasi sebesar 78,2\% dari 100\% rekomendasi yang harus dilaksanakan. Hal ini makin diperparah dengan pemeriksaan tahun 2015-2018 yang dimana pelaksanaan sesuai dengan rekomedasi sebesar 75,8\% dari 100\% yang harus diselesaikan.

Setiap negara di dunia tentu mengalami permasalahan yang sama dalam pengelolaan keuangan negara, hanya saja yang membedakan dari Indonesia adalah sistem yang dibangun dalam pengelolaannya. Pada masa orde baru yang bersifat otoriter dalam pengambilan kebijakan maka berimbas pula pada sistem pengelolaan keuangan negara yang menjadi sentralistik, artinya semua keuangan baik dari daerah ditarik semua ke pemerintah pusat dan kemudian pemerintah pusat yang menentukan anggaran dari pemerintah daerah.

Sistem sentralistik tersebut menjadikan ketergantungan daerah pada pemerintah pusat yang cukup tinggi, selain itu dengan sistem sentralistik sulit akan menemukan transparansi pengelolaan keuangan negara, sehingga munculah tindakan yang kemudian dikenal dengan KKN.

Pada era reformasi KKN telah dilarang melalui TAP MPR RI dan juga undang-undang. Peraturan tersebut mungkin tidak dapat menghapus langsung kejahatan KKN setidaknya meminimalisir kejahatan KKN tersebut. Kemudian guna mengubah sistem sentralistik pengelolaan keuangan negara, dalam sidang istimewa MPR RI mengubah pengelalolaan pemerintahan dan keuangan daerah menjadi desentralisasi atau yang lebih dikenal dengan otonomi daerah.

Permasalahan yang muncul dengan menjalankan sistem sentralistik dalam pengelolaan keuanagan negara oleh penulis dikategorikan menjadi 2 (dua) permasalahan. Pertama, aparat pemerintahan yang masih bersifat ingin menggunakan jabatan yang dimiliki untuk memperkaya diri. Iman Anis mengatakan bahwa peraturan perundang-undangan adalah suatu instrumen untuk melakukan rekayasa sosial dan politik, sehingga dapat dilakukan oleh Dewan Perwakilan Rakyat Daerah (DPRD) untuk memanipulasi Anggaran 
Pendapatan dan Belanja Daerah (APBD) dan akhirnya ditindaklanjuti sebagai tindakan pidana merugikan keuangan negara. ${ }^{9}$ Philipus M. Hadjon mengatakan bahwa korupsi APBD ditinjau dari Hukum Tata Negara dan Hukum Administrasi diukur dari fungsi APBD dan asas spesialitas dan pengelolaan keuangan anggaran. ${ }^{10}$ Artinya bahwa jika pejabat daerah dan anggota legislatif tidak memanfaatkan APBD sesuai dengan peraturan perundang-undangan dan kegunaan dari APBD itu, maka peluang melakukan korupsi di daerah menjadi semakin besar.

Muhamat Yusup dam Y. Yani Aryani menjelaskan juga bahwa karakteristitik kepala daerah yang diposisikan sebagi incumbent, tingkat pendidikan, usia dan faktor afiliasi partai politik kepala daerah berpengaruh positif signifikan terhadap indikasi korupsi belanja modal. ${ }^{11}$ Permasalahan ketidakpatuhan juga menjadi sorotan dalam temuan audit keuangan BPK baik ketidakpatuhan terhadap peraturan perundang-undangan berpengaruh negatif terhadap pemberian opini yaitu temuan yang mengakibatkan adanya kerugian daerah, potensi kerugian daerah, penyimpangan administrasi dan ketidakhematan. ${ }^{12}$

Berdasarkan penjabaran kesemuanya bahwa permasalahan pertama terkait tentang sifat maupun karakter dari pejabat-pejabat daerah, baik kepala daerah dan satuan pemerintahannnya maupun dari pihak legislatif yaitu DPRD. Sehingga diperlukan revisi terhadap UU BPK dan peraturan yang terkait agar permasalahan ini dapat diatasi, sehingga berbagai permasalahan di atas dapat dicegah.

9 Iman Anis, Manipulasi Anggaran Belanja APBD oleh DPRD Sidoarjo (Kajian Putusan No. 371/Pid.B/2004/Pn.Sda, Jurnal Kajian Putusan Pengadilan Dictum Edisi 5 2005, Jakarta, 2005, hlm., 51.

10 Philipus M. Hadjon, Analisis Korupsi APBD oleh Anggota DPRD Ditinjau dari Sudut Pandang Hukum Tata Negara dan Hukum Administrasi, Jurnal Kajian Putusan Pengadilan Dictum Edisi 5 2005, Jakarta, 2005, hlm., 63.

11 Muhamat Yusup dam Y. Yani Aryani, Karakteristik Kepala Daerah, Afiliasi Partai Politik dan Indikasi Korupsi Belanja Modal, Jurnal Integritas Volume 1 Nomor 1 November 2015, Jakarta, 2015, hlm., 76.

12 RM Syah Arief Atmaja W dan Agung Nur Probohudono, Analisis Audit BPK RI Terkait Kelemahan SPI, Temuan Ketidakpatuhan dan Kerugian Negara, Jurnal Integritas Volume 1 Nomor 1 November 2015, Jakarta, 2015, hlm., 106. 
Kedua, pengamatan penulis tertuju pada sistem laporan keuangan yang disusun oleh satuan pemerintahan daerah di seluruh Indonesia dengan menggunakan data IHPS antara tahun 2015-2018.13 Di sini tidak terdapat "unifikasi hukum" dalam artian jika itu membahas hal yang sama seperti bidangbidang yang menjadi tanggung jawab pemerintah daerah, maka hal ini harusnya menjadi bahan kajian antara pemerintah pusat dan DPR dengan hasil pemeriksaan BPK untuk menyusun suatu rumusan yang bersifat satu di bidang pelaporan keuangan. Penulis meneliti dari IHPS dari 201-2015 terkait tiga fokus pemeriksaan oleh BPK, yaitu pemeriksaan keuangan, kinerja dan tujuan tertentu (Ikhtisar Hasil Pemeriksaan Semester 2015-2018). ${ }^{14}$ Seperti contoh pemungutan pajak dan retribusi daerah di bidang pajak kendaraan ada suatu daerah yang menerapkan e-samsat, namun daerah lainnya masih bersifat manual sehingga pelaporan keuangan dan realisasi target pajak daerah tidak terkontrol karena sistem yang masih manual.

Pada dasarnya sistem pemerintahan daerah memang harusnya menjadi fokus dan tanggung jawab dari daerah-daerah itu sendiri. ${ }^{15}$ Namun tidak sertamerta Pemerintah Pusat melepas begitu saja dan menjadikan BPK hanya sebagai lembaga yang hanya sekedar untuk melakukan pemeriksaan keuangan sebagaimana yang tertuang dalam UU BPK yaitu dengan adanya penempatan perwakilan BPK yang tersebar di setiap Provinsi ${ }^{16}$. Kementerian Dalam Negeri yang merupakan turunan dari Pemerintah Pusat seharusnya bisa berkoordinasi dengan BPK terkait dengan pelaporan keuangan, sehingga BPK mempunyai kewenangan memberi rekomendasi kepada Pemerintah Pusat tentang pengelolaan keuangan negara oleh pemerintah daerah.

Sistem pelaksanaannya, yaitu bahwa ada suatu daerah yang melakukan suatu pelaporan dan sistem keuangan daerah yang bagus dan tepat sasaran sehingga bisa dibahas di dalam rapat kabinet mengenai sistem pelaporan

\footnotetext{
13 Ikhtisar Hasil Pemeriksaan Semester II Tahun 2018 oleh Badan Pemeriksa Keuangan

14 Id.

15 Muhammad Fauzan, Hukum Pemerintahan Daerah, Kajian Hubungan Keuangan Antara Pemerintah Pusat dan Daerah, STAIN Press Purwokerto, Purwokerto, 2010, hlm., 191.

16 Lihat Undang-Undang Nomor 15 Tahun 2006 tentang Badan Pemeriksa Keuangan Pasal 3.
} 
keuangan yang tepat yang bisa diterapkan di seluruh satuan pemerintahan di Indonesia dengan melakukan beberapa penyempurnaan berdasarkan rapat antara Pemerintah Pusat, Dewan Pewakilan Rakyat (DPR), Dewan Pewakilan Rakyat Daerah (DPRD), maupun BPK.17

Sebagaimana dijelaskan oleh Bagir Manan, sesuai dengan pembawaannya (karakteristiknya), urusan keuangan dimanapun senantiasa dikategorikan sebagai urusan yang diatur dan diurus oleh Pusat. ${ }^{18}$ Selaim itu tujuannya adalah untuk memaksimalkan keuangan negara untuk digunakan kemanfaatan bersama di dalam kehidupan berbangsa dan bernegara. Hal inilah yang akan dibahas di dalam pembahasan kedua mengenai perlunya perluasan kewenangan BPK dalam melakukan pemeriksaan keuangan di dalam satuan pemerintahan daerah agar tindakan merugikan negara, potensi KKN dapat dicegah, serta adanya unifikasi hukum suatu aturan pelaporan keuangan yang ditujukan oleh seluruh satuan pemerintahan daerah agar pelaporan keuangan daerah yang dibuat benar-benar dapat dipertangungjawabkan baik secara hukum dan sesuai dengan peruntukannya. ${ }^{19}$

\section{Perluasan Kewenangan BPK Dalam Mengawasi Keuangan Negara di Lingkup Pemerintahan Daerah}

Pembahasan sebelumnya menyatakan bahwa politik hukum dibentuknya BPK, yaitu agar meminimalisir timbulnya kerugian dalam pengelolaan keuangan negara. Problematika yang akan di kaji adalah belum efektifnya kehadiran BPK saat ini. Hal tersebut dapat dilihat dari tindak lanjut dari pemerintahan daerah terhadap rekomendasi yang diberikan oleh BPK. Meskipun di dalam ketentuan jika tidak melakukan rekomendasi yang diberikan oleh BPK akan dikenakan

17 Gilang Prama Jasa dan Ratna Herawati, Dinamika Relasi Antara Badan Pemeriksa Keuangan dan Dewan Perwakilan Rakyat dalam Sistem Audit Keuangan Negara, Jurnal Law Reform Volume 13, Nomor 2, Tahun 2017, Semarang, 2017, hlm., 193.

18 Bagir Manan, Hubungan antara Pusat dan Daerah Menurut UUD 1945, Pustaka Sinar Harapan, Jakarta, 1994, hlm., 205.

19 Risma Diri Artha et.al, Pengaruh Karakteristik Pemerintah Daerah dan Temuan Audit BPK Terhadap Kinerja Penyelenggaraan Pemerintahan Daerah (Studi Empiris Pada Pemerintah Kabupaten/Kota Di Provinsi NTB), Jurnal InFestasi Vol. 11, No.2, Desember 2015, Mataran, 2015, hlm., 215. 
hukuman baik administrasi maupun pidana namun masih tidak berpengaruh terhadap kepatuhan satuan pemerintahan daerah untuk segera melakukan suatu perbaikan sesuai rekomendasi BPK.

Kewenangan BPK selama ini hanya sebatas mengaudit atau memeriksa unsur-unsur apa saja yang telah dipenuhi oleh pemerintah baik pusat maupun daerah dalam mengelola keuangannya. Pada proses mengaudit atau memeriksa keuangan seperti temuan berupa penyimpangan yang terjadi BPK hanya dapat melakukan rekomendasi ke lembaga lain, yaitu kepolisian atau kejaksaan untuk pemeriksaan lebih lanjut. ${ }^{20}$

Berdasarkan hal tersebut dapat dijabarkan bahwa ada beberapa tahapan yang memang harus ada yang harus dilakukan oleh BPK dimana hal ini harus mampu dijalankan agar terjadi keseimbangan dan kesinambungan antara lembaga negara dalam mengelola keuangannya tentang menghindari penyimpangan.

Tahapan yang harus ada dalam melaksanakan kewenangan BPK di antaranya sebagai berikut, permasalahan dimulai dari kebijakan keuangan negara yang masih belum adanya "unifikasi hukum". Unifikasi di sini, yaitu terkait pelaporan keuangan yang dilakukan oleh satuan pemerintahan daerah. Perubahan budaya kerja di lembaga pengguna keuangan ini tanpa mekanisme kendali menyeluruh yang dibangun bersamaan dengan perubahan budaya kerja dan sikap mental, adalah mustahil untuk menjamin terintegrasinya formulasi dan implementasi dengan tujuan kebijakan keuangan negara secara berkesinambungan. ${ }^{21}$ Di sini penulis akan menjabarkan mengenai formulasi pelaporan sistem keuangan yang dikaitkan dengan pengawasan dalam penggunaan APBD. Pengawasan di sini, yaitu baik dalam unsur penerimaan keuangan maupun pengeluaran.

20 Lihat ketentuan Undang-Undang Nomor 15 Tahun 2006 tentang Badan Pemeriksa Keuangan Pasal 24-25 tentang Tindakan Kepolisian terhadap suatu perkara keuangan setelah adanya pemeriksaan dari BPK.

21 Zukra Budi Utama, Anomali Kebijakan Keuangan Negara dan Solusinya Melalui Perubahan Budaya Kerja di Lembaga Pengguna Anggaran, Jurnal Integritas Volume 1 Nomor 1 November 2015, Jakarta, 2015, hlm., 138. 
Mengutip pendapat Soebagio bahwa agar terjadi keseimbangan dalam menjalankan kewenangan harus ada konfigurasi pembaharuan sistem yaitu, penggabungan metode pengawasan dari segi objeknya dapat dibagi dua baik dari segi penerimaan daerah maupun dari segi pengeluaran daerah. Hal ini sebagai bentuk telah dilakukannya pengawasan baik secara preventif maupun represif yang telah diterapkan di lingkup interen maupun eksteren. ${ }^{22}$

Perlu digarisbawahi bahwa perluasan kewenangan BPK mengacu pada unsur pemeriksaan keuangan, kinerja dan tujuan tertentu. Pokok utama, yaitu terkait APBD yang merupakan gabungan antara suatu penerimaan daerah dan pengeluaran daerah. Pembaharuan sistem yang akan diuraikan penulis, yaitu baik dalam penerimaan maupun pengeluaran harus wajib juga dilaporkan oleh BPK yang termuat dalam suatu sistem IT yang mendukung kinerja agar pelaporan menjadi real time dan dapat secara online.

Satuan pemerintahan daerah mempunyai kewajiban untuk melaporkan kegiatan penerimaan daerah yang akan tercatat secara otomatis oleh sistem di BPK pada setiap akhir bulan. Mengapa setiap bulan? Ini merupakan suatu revolusi dalam melakukan pemeriksaan audit bagi BPK dapat bekerja secara efektif dan efisien sehingga tidak perlu membutuhkan waktu yang lama untuk memeriksa dan memberi rekomendasi satuan pemerintahan daerah.

Dasar dari penyesuaian laporan pengelolaan keuangan negara adalah bahwa perluasan kewenangan BPK untuk mengetahui rincian APBD seluruhnya dari satuan pemerintahan daerah tanpa terkecuali. Sehingga ketika mendapatkan suatu laporan mengenai penerimaan keuangan daerah, pihak BPK dapat langsung melakukan audit serta memeriksaan satuan penerimaan daerah berdasarkan dokumen legal yaitu APBD yang telah disahkan sebelumnya. Apabila ditemukan kekurangan akan segera diberikan rekomendasi oleh BPK untuk segera ditindaklanjuti.

22 M. Soebagio, Hukum Keuangan Negara RI, Rajawali Press, Cetakan II, Jakarta, 1991, hlm., 94102. 
Hal ini berguna untuk mengidentifikasi lebih awal kekurangan dalam laporan pengelolaan keuangan yang merupakan hasil dari penerimaan keuangan daerah, yang diserahkan setiap bulan oleh BPK agar segera diperbaiki oleh pemerintah daerah, karena bagaimanapun BPK tidak dapat berjalan sendiri perlu adanya kerjasama antar lembaga negara yang lain baik di pemerintahan pusat hingga pemerintahan daerah guna terjaganya kestabilan ekonomi serta pembangunan yang merata, selain itu juga meminimalisir penyalahgunaan keuangan negara oleh oknum-oknum di kalangan pemerintahan baik pusat maupun daerah agar penyalurannya tepat guna dan tepat sasaran.

Pembahasan tentang pengeluaran daerah hampir sama dengan konsep di atas, dimana terdapat tahap-tahap di dalam proses pengeluaran daerah. Pengawasan terhadap pengeluaran negara, yakni pengawasan dilakukan pada waktu sedang atau sesudah operasional, dan pengawasan sebelum dilakukan pengeluaran, terdiri atas:

1. Pengawasan pada waktu perencanaan pengeluaran, yaitu melalui perencanaan atau pengusulan sampai menjadi Daftar Informasi Publik (DIP) dan Daftar Informasi Dikecualikan (DIK).

2. Pengawasan pada waktu akan melakukan pengeluaran, yaitu oleh ordonator terhadap tagihan melalui SPPR/SPPP dan penelitian terhadap Surat Perintah Membayar Uang (SPMU).

3. Pengawasan pada waktu akan dilakukan pembayaran dimana bendaharawan harus mendapat pengesahan terlebih dahulu dari Kepala Kantor atau atasan langsung.

4. Pengawasan pada waktu setelah terjadi pengeluaran, yaitu kepala kantor atau atasan langsung harus memeriksa tanda bukti pengeluaran dan melegalisir SPJ yang akan dikirimkan ordonator.

5. Pengawasan yang dilakukan oleh ordonator atau otorisator dalam hal ini oleh Biro Keuangan cq. Bagian pembukuan dan verifikasi Kementerian terhadap Surat Pertanggung Jawaban (SPJ). 
6. Pengawasan BPK terhadap SPJ yang telah diperiksa oleh ordonator atau Bagian Anggaran. Pengawasan ini adalah pengawasan terakhir bagi bendaharawan. ${ }^{23}$

Di sini telah dilakukan konstruksi dimana angka 1 hingga 5 meskipun tetap dilakukan pengawasan ini masih dalam lingkup pengawasan interen, baru pada angka 6 pengawasan berada di pihak eksteren yaitu BPK. Di sini perlu adanya koordinasi sehingga ketika pelaporan berada di tahap akhir, yaitu BPK harus adanya kerjasama dan koordinasi untuk melakukan pelaporan kepada BPK oleh bendaharawan terhadap setiap kegiatan pengeluaran daerah, yaitu setiap bulan tepatnya pada akhir bulan. Hal ini memiliki tujuan yang sama seperti halnya konsep pelaporan pada penerimaan daerah yaitu untuk melakukan kontrol atas pengeluaran yang dilakukan oleh daerah sehingga dapat diantisipasi dengan cepat baik itu BPK berupa rekomendasi yang harus segera diperbaiki dan dari pihak satuan pemerintahan daerah dapat segera mengatasinya.

Konsep kesemuanya baik penerimaan maupun pengeluaran daerah penulis mengkaji sistem terbaru perlu dilakukan pelaporan rutin secara online dan realtime, yaitu untuk mencegah secara awal agar tidak terjadi risiko kerugian keuangan daerah, dan segera dapat diantisipasi baik oleh BPK dan oleh satuan pemerintahan daerah. Sehingga tindakan KKN dapat diminimalisir dan bahkan tidak terjadi karena sifat koordinasi yang dilakukan secara berkesinambungan agar terhindar dari adanya suatu kerugian daerah.

APBD merupakan suatu kebebasan bagi pemerintahan daerah dalam merumuskan dan merancang anggaran daerah serta pendapatan daerah yang harus dioptimalkan dalam rangka pembangunan daerah yang lebih baik dan yang utama sesuai dengan kebutuhan daerah itu. ${ }^{24}$

Hubungan APBD dengan permasalahan karakter dari pejabat-pejabat daerah, yaitu dalam merealisasikan APBD sesuai dengan tujuan dan

23 Josep M Monteiro, Pokok-Pokok Hukum Keuangan Negara \& Daerah, Inteligensia Media, Malang, 2017, hlm., 124.

24 Anggit Sulistiawan et.al, Bentuk dan Mekanisme Perencanaan Keuangan Daerah yang Partisipatif Guna Mewujudkan Akuntabilitas Publik, Jurnal Pembangunan Hukum Indonesia Volume 1, Nomor 2, Tahun 2019, Semarang, 2019, hlm., 148. 
peruntukannya. Artinya APBD dapat dikategorikan berhasil jika pertumbuhan perekonomian di daerah tersebut maju. Perekonomian daerah maju karena pengelolaan APBD yaitu terkait dengan penerimaan daerah dan pengeluaran daerah dilakukan secara transparan dan akuntabilitas. Di sini akan dilakukan kajian perluasan kewenangan BPK bahwa jika dalam pelaksanaan rekomendasi dari BPK terkait penerimaan maupun pengeluaran daerah yang mengakibatkan adanya suatu kerugian keuangan dan potensi kerugian karena tidak dilaksanakannya rekomendasi dari BPK, maka BPK memiliki suatu kewenangan.

APBD dibuat oleh Pemerintah Daerah dengan persetujuan DPRD. Di sini perluasan kewenangan dari BPK, yaitu bahwa sebelum dilakukannya pembuatan APBD untuk tahun berikutnya, Pemerintah Daerah wajib melaporkan jumlah total realisasi dari rekonmendasi yang diberikan oleh BPK kepada Pemerintah Daerah terkait pemeriksaan keuangan. Jika masih belum yang ditindaklanjuti BPK dapat memiliki kewenangan untuk menyuruh Pemerintah Daerah yang terkait untuk segera menyelesaikan rekomendasi BPK guna untuk menutupi kerigian keuangan daerah yang ada. BPK juga memiliki hubungan dengan DPRD dimana untuk tidak mengesahkan APBD dalam hal Pemerintah Daerah masih belum melaksanakan rekomendasi dari BPK terkait pemeriksaan keuangan di daerah tersebut. Konsekuensi logis, yaitu bahwa adanya tuntutan dari Pemerintah Daerah tersebut agar memiliki tanggung jawab dalam mengelola keuangan daerah yang telah diperiksa oleh BPK agar segera dilakukan pembenahan dan kerugian keuangan daerah dapat segera kembali ke kas daerah.

Pertanyaan muncul jika masih adanya keengganan dari pemerintah daerah untuk melaksanakan rekomendasi dari BPK dan ternyata APBD tahun berikutnya dibuat, maka BPK dapat meminta kepada DPRD untuk mencegah hal tersebut. Jika ternyata APBD tahun berikutnya sudah dibuat dan disahkan oleh DPRD setempat, maka BPK dapat menjadikan hal tersebut sebagai suatu tindakan pidana, yaitu berupa kelalaian yang akan menjadi pembaharuan hukum sanksi di dalam undang-undang BPK. Selain itu juga diterapkan sanksi administrasi negara dimana BPK dapat melaporkan kepada Pemerintah Pusat untuk menurunkan jabatan dari setiap pejabat daerah yang melakukan kelalaian dalam hal menyelamatkan 
keuangan di daerah yang ternyata jika tidak ditindaklanjuti akan menimbulkan potensi kerugian keuangan di daerah tersebut. ${ }^{25}$

Berdasarkan penjabaran butir kesatu dan kedua, perlu adanya pembaharuan dan revisi tentang pelaksanaan pelaporan keuangan yang bersifat sistematis, transparan dan akuntabel yang terintegrasi secara online dan realtime untuk menghindari potensi kerugian keuangan daerah dan mencegah terjadinya praktek KKN. Selain itu perlunya pembaharuan Undang-Undang BPK mengenai sanksi baik pidana maupun administrasi terkait adanya kelalaian dari satuan pemerintahan daerah yang ternyata tidak melaksanakan rekomendasi dari BPK yang bertujuan untuk menyelamatkan keuangan daerah agar tidak terjadi kerugian keuangan lebih banyak lagi, maka harus diberikan sanksi yang tegas kepada aparat pemerintahan tersebut baik pidana maupun administrasi sebagaimana yang telah diuraikan di atas. Inilah yang dinamakan sistem yang bersifat Checks and Balances dalam mengelola keuangan dalam mewujudkan transparansi dan akuntabilitas pengelolaan keuangan. ${ }^{26}$

Tujuan dari pembaharuan tentang kewenangan BPK adalah untuk meminimalisir terjadinya kerugian keuangan di daerah, sebagai langkah awal untuk nencegah terjadinya KKN. Transformasi kinerja dengan cara merubah pola kerja dari satuan pemerintahan daerah agar segera mempertanggungjawabkan segala kegiatan yang berhubungan dengan keuangan agar dapat segera ditemukan solusinya oleh BPK serta dapat ditindaklajuti rekomendasi tersebut oleh satuan pemerintahan daerah.

Adanya hubungan antar sistem pemerintahan dan antar lembaga, yaitu BPK dengan Pemerintah Daerah dalam hal mengcek kondisi rekomendasi dari BPK bertujuan agar tercipta beban moril untuk segera menyelesaikan rekomendasi tersebut untuk mengembalikan kerugian keuangan daerah. Begitu

25 Arnold Nicodemus Musa, Kajian Hukum atas Opini BPK RI Terhadap Laporan Pengelolaan dan Pertanggungjawaban Keuangan Pemerintah Daerah (Studi Kasus Pada Pemerintah Kabupaten Halmahera Barat), Lex et Societatis, Vol. III/No. 2/Mar/2015/Edisi Khusus, Sulawesi Utara, 2015, hlm., 79-80.

26 Hendar Ristriawan dan Dewi Kania Sugiharti, Penguatan Pengelolaan Keuangan Negara Melalui Mekanisme Checks and Balances System, Jurnal Konstitusi Volume 14 Nomor 3 September 2017, Bandung, 2017, hlm., 601. 
juga hubungan antara BPK dan Dewan Perwakilan Rakyat (DPR) yang telah dirumuskan di dalam Pasal 7 ayat (1) UU BPK.

Penyerahan hasil audit dari BPK kepada Dewan Perwakilan Rakyat (DPR) tersebut merupakan salah satu Fungsi Pengawasan Dewan Perwakilan Rakyat (DPR) atas pelaksanaan Undang-Undang dan Anggaran Pendapatan dan Belanja Negara (APBN). Hal ini juga harus dituangkan dalam hubungan antara BPK dengan DPRD di daerah agar dalam melakukan pengawasan DPRD dapat meminta kepada BPK untuk melakukan tindakan lebih lanjut atas pelaporan pemeriksaan keuangan dari BPK. Salah satunya memantau pelaksaaan rekomendasi pemeriksaan keuangan di daerah. ${ }^{27}$

\section{Penutup}

Politik hukum dibentuknya BPK yaitu agar dalam melakukan suatu pengelolaan keuangan negara benar-benar ditujukan sesuai dengan peruntukannya dan sesuai dengan cita-cita hukum UUD NRI Tahun 1945. Hal ini juga untuk tujuan reformasi dimana agar daerah dalam mengelola keuangan daerah bisa bersifat transparan dan akuntabilitas dan mencegah terjadinya KKN yang terjadi pada masa Orde Baru.

Permasalahan yang muncul, yaitu maraknya KKN yang terjadi di satuan pemerintahan daerah pada Era Reformasi terjadi karena dua faktor, yaitu karena sifat dan karakter dari kepala daerah dan afiliasi dari partai politik dalam memanfaatkan jabatannya untuk memanipulasi APBD untuk tujuan pribadi, dan sistem pengelolaan keuangan yang dikaji di berbagai daerah tidak adanya suatu "unifikasi hukum" sehingga menjadikan adanya ketidakcermatan dan ketidakefisien yang berdampak menimbulkan potensi kerugian keuangan daerah.

Perluasan kewenangan BPK dalam pemeriksaan keuangan di lingkup pemerintahan daerah yaitu dapat dijelaskan di dalam dua tahap. Pertama, sistem penerimaan dan pengeluaran daerah harus terintegrasi secara online dan realtime oleh BPK dengan pelaporan yang dilakukan oleh bendaharawan setiap bulan

27 Gilang Prama Jasa, Supra no. 17, hlm., 201. 
sekali. Patokan dari BPK yaitu APBD yang diperoleh dari seluruh satuan pemerintahan daerah di seluruh wilayah di Indonesia. Hal ini untuk mengoptimalkan dalam pemeriksaan keuangan oleh BPK yang langsung segera memberikan rekomendasi tindak lanjut yang harus dilakukan oleh satuan pemerintahan daerah untuk mencegah potensi kerugian keuangan daerah. Kedua, BPK memiliki kewenangan untuk mengecek kepada Pemerintah Daerah, yaitu Kepala Daerah terhadap rekomendasi BPK yang telah dilaksanakan terkait hasil pemeriksaan keuangan oleh BPK.

Hubungan BPK dengan DPRD, yaitu meminta untuk tidak mengesahkan APBD jika Pemerintah Daeah masih belum melaksanakan rekomendasi dari BPK dalam hal mencegah terjadinya kerugian keuangan daerah. Karenanya diperlukan revisi undang-undang untuk perluasan kewenangan BPK mengenai fungsi di atas sehingga dapat meminimalisir terjadinya KKN dan mengoptimalkan penggunaan APBD agar sesuai dan tepat sasaran sesuai yang diamanatkan oleh UUD NRI Tahun 1945 yaitu untuk digunakan sebesar-besar kemakmuran masyarakat.

\section{Daftar Pustaka}

\section{Buku:}

Bagir Manan, Hubungan antara Pusat dan Daerah Menurut UUD 1945, Pustaka Sinar Harapan, Jakarta, 1994.

Erman Rajagukguk, et.al., Perubahan Hukum di Indonesia (1998-2004), Harapan 2005, Legal Development Facility - Fakultas Hukum Universitas Indonesia, Jakarta, 2004.

Jimly Asshiddiqie, Hukum Tata Negara dan Pilar-Pilar Demokrasi, Serpihan Pemikiran Hukum, Media dan HAM, Konstitusi Press, Jakarta, 2005.

Josep M Monteiro, Pokok-Pokok Hukum Keuangan Negara \& Daerah, Inteligensia Media, Malang, 2017. 
M. Laica Marzuki, Berjalan-jalan di Ranah Hukum: Pikiran-Pikiran Lepas Prof. Dr. H. M. Laica Marzuki, S.H., Konstitusi Press, Jakarta, 2005.

M. Soebagio, Hukum Keuangan Negara RI, Rajawali Press, Cetakan II, Jakarta, 1991.

Muhammad Fauzan, Hukum Pemerintahan Daerah, Kajian Hubungan Keuangan Antara Pemerintah Pusat dan Daerah, STAIN Press Purwokerto, Purwokerto, 2010.

Romli Atmasasmita, Pengantar Hukum Kejahatan Bisnis, Kencana, Jakarta, 2003.

\section{Jurnal:}

Andini Rahmayanti Pontoh, Tugas dan Wewenang BPK dalam Pengawasan Pengelolaan Keuangan BUMN/D, Lex Administratum, Vol.I/No.1/JanMrt/2013, 2013.

Anggit Sulistiawan et. al, Bentuk dan Mekanisme Perencanaan Keuangan Daerah yang Partisipatif Guna Mewujudkan Akuntabilitas Publik, Jurnal Pembangunan Hukum Indonesia Volume 1, Nomor 2, 2019.

Arnold Nicodemus Musa, Kajian Hukum atas Opini BPK RI Terhadap Laporan Pengelolaan dan Pertanggungjawaban Keuangan Pemerintah Daerah (Studi Kasus Pada Pemerintah Kabupaten Halmahera Barat), Lex et Societatis, Vol. III/No. 2/Mar/2015/Edisi Khusus, 2015.

Bambang Waluyo, Optimalisasi Pembrantasan Korupsi Di Indonesia, Jurnal Yuridis Vol. 1 No. 2, Desember, 2014.

Gilang Prama Jasa dan Ratna Herawati, Dinamika Relasi Antara Badan Pemeriksa Keuangan dan Dewan Perwakilan Rakyat Dalam Sistem Audit Keuangan Negara, Jurnal Law Reform Volume 13 Nomor 2, 2017.

Hendar Ristriawan dan Dewi Kania Sugiharti, Penguatan Pengelolaan Keuangan Negara Melalui Mekanisme Checks and Balances System, Jurnal Konstitusi Volume 14 Nomor 3, 2017.

Muhammad Imron Rosyadi, Wewenang Badan Pemeriksa Keuangan dan Badan Pengawasan Keuangan dan Pembangunan dalam Menilai Kerugian Keuangan Negara, Mimbar Keadilan, Jurnal Ilmu Hukum Januari - Juni 2016.

Muhamat Yusup dam Y. Yani Aryani, Karakteristik Kepala Daerah, Afiliasi Partai Politik dan Indikasi Korupsi Belanja Modal, Jurnal Integritas Volume 1 Nomor 1, 2015.

Philipus M. Hadjon, Analisis Korupsi APBD oleh Anggota DPRD Ditinjau dari Sudut Pandang Hukum Tata Negara dan Hukum Administrasi., Jurnal Kajian Putusan Pengadilan Dictum Edisi 5, 2005.

Risma Diri Artha et. al, Pengaruh Karakteristik Pemerintah Daerah dan Temuan Audit BPK Terhadap Kinerja Penyelenggaraan Pemerintahan Daerah (Studi Empiris Pada Pemerintah Kabupaten/Kota Di Provinsi NTB), Jurnal InFestasi Vol. 11, No.2, 2015.

RM Syah Arief Atmaja W dan Agung Nur Probohudono, Analisis Audit BPK RI Terkait Kelemahan SPI, Temuan Ketidakpatuhan dan Kerugian Negara, Jurnal Integritas Volume 1 Nomor 1, 2015. 
Zukra Budi Utama, Anomali Kebijakan Keuangan Negara dan Solusinya Melalui Perubahan Budaya Kerja di Lembaga Pengguna Anggaran, Jurnal Integritas Volume 1 Nomor 1, 2015.

\section{Peraturan:}

Undang-Undang Dasar Negara Republik Indonesia Tahun 1945.

Undang-Undang Nomor 17 Tahun 2003 tentang Keuangan Negara.

Undang-Undang Nomor 1 Tahun 2004 tentang Perbendaharaan Negara.

Undang-Undang Nomor 15 Tahun 2004 tentang Pemeriksaan Pengelolaan dan Tanggung Jawab Keuangan Negara.

\section{Lain-Lain:}

BPK, Ikhtisar Hasil Pemeriksaan Semester II, Jakarta: Badan Pemeriksa Keuangan, 2018. 